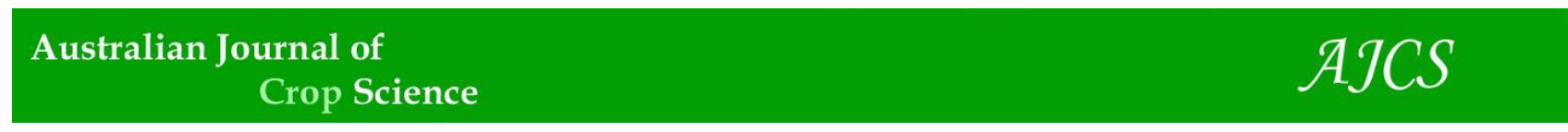

AJCS 11(08):1026-1032 (2017)

ISSN:1835-2707

doi: 10.21475/ajcs.17.11.08.pne558

\title{
Boron fertilisation at different phenological stages of soybean
}

\section{Ivana da Silva Gomes ${ }^{1}$, Cleiton Gredson Sabin Benett ${ }^{1,2^{*}}$, Rogerio Lamim Silva Junior ${ }^{1}$, Ricardo Caldas Xavier ${ }^{1}$, Katiane Santiago Silva Benett ${ }^{1}$, Anderson Rodrigo da Silva ${ }^{2}$ and Ademilson Coneglian ${ }^{1}$}

\author{
${ }^{1}$ State University of Goiás (Universidade Estadual de Goiás), Campus Ipameri, highway G0-330, km 241, 75780- \\ 000 Zip, Ipameri, Goias, Brazil \\ ${ }^{2}$ Federal Institute Goiás (Instituto Federal Goiano), Campus Urutaí, highway Geraldo Silva Nascimento, km 2.5, \\ 75790-000 Zip, Urutaí, Goias, Brazil
}

*Corresponding author: cleiton.benett@gmail.com

\begin{abstract}
The high global food demand has led to crop management practices such as the use of micronutrients to increase soybean productivity. The aim of the present study was to evaluate the effect of boron fertilisation applied to two varieties of soybeans at different doses and different phenological stages on yield components, productivity and physiological quality of seeds. Two different soybean varieties were tested, one conventional (variety BRS 7980) and one transgenic (variety M 7739 IPRO), in two field experiments performed in parallel during the 2014/2015. A randomised block experimental design was used in both experiments, with a 3 x 5 factorial scheme, with four replicates per treatment. The tested factors were three phenological stages (V6, V9 and R1) and five boron doses $\left(0,1,2,3\right.$ and $\left.4 \mathrm{~B} \mathrm{~kg} \mathrm{ha}^{-1}\right)$. The following parameters were analysed: leaf boron concentration, chlorophyll concentration, yield components and productivity. Boron fertilisation at different phenological stages had no effect on most agronomic traits, but it did increase productivity in both varieties, independent of the phenological stage of application. The boron dose indicated for maximum production for both varieties is $3.51 \mathrm{~kg} \mathrm{~B} \mathrm{ha}^{-1}$.
\end{abstract}

Keywords: Glycine Max L., plant nutrition, productivity.

Abbreviations: B_boron; V_varieties; S_stage; D_dose; LBC_leaf boron concentration; CHL_chlorophyll; PH_plant height; SD_stem diameter; HPI_height of first pod insertion; NP_number of pods; PL_pod length; NB_number of beans per plant; W100_weight of 100 beans; PROD_productivity.

\section{Introduction}

Soybean (Glycine Max L.) is grown worldwide. Its adaptability and high productivity depend on crop management techniques and on constant advances in genetic improvement methods, enabling ongoing improvement of soybean ancestral lines with the goal of selecting the most desired characteristics.

Brazil is the second largest soybean producer and exporter in the world. Brazil's soybean cultivation area has increased significantly over the last few years, becoming the primary reason for frontier agricultural expansion (Conab, 2016). Soybeans are widely consumed by humans and animals due to their high nutritional value, including good digestibility, adequate essential amino acids and total nitrogen content, and excellent protein source, and they are also used as raw matter in different agro-industries (Ferreira Junior et al., 2010; Pires et al., 2006). However, adequate crop management and nutrient supply, among other practices, are necessary to improve soybean production and achieve high productivity.

The increase in Brazilian soybean production and production capacity are linked to scientific advances and new production technologies, such as the use of mineral fertilisers (Suzana et al., 2012; Peske et al., 2012; Souza et al., 2008). In addition, increasingly resistant and productive soybean seeds and cultivars are obtained through genetic improvement.
Although the majority of the international market, especially the European and Japanese markets, prefers conventional soybeans, the cultivation and commercialisation of genetically modified crops predominates in Brazil (Pelaez et al., 2004; Cunha et al., 2015). Brazilian soils are sandy and poor in organic matter. Consequently, they are very often deficient in some micronutrients, e.g., boron (B). Crop management practices, such as the adequate timing of fertiliser application, may therefore help increase soybean productivity and quality. Boron application to soybeans is mostly performed through foliar fertilisation due to the ease of application, supplying the plants with nutrients that are quickly absorbed. However, mineral fertilisers are most efficient when applied to the soil due to the high capacity of roots for water and nutrient uptake (Malavolta, 1989). Some plants, such as almond, apple and nectarine trees, have polyols as a component of their phloem sap, which forms a complex with boron ions, making it phloem mobile. However, in many plant species, boron is not phloem mobile. In such species, the most efficient way of applying B is to the soil (Brown and Hu, 1994).

Boron is essential for plant growth and development, playing a role in physiological processes such as sugar transport, respiration, lignification, nitrogen fixation, cell 
wall structure, carbohydrate, phenol, indoleacetic acid (IAA), ribonucleic acid (RNA), IAA and ascorbate metabolism, cell wall synthesis and plasma membrane integrity (Trautmann, 2014; Reis et al., 2008; Marschner, 1995). Boron deficiency is the most common micronutrient limitation in plants (Raimundi et al., 2013; Blevins and Lukaszewski, 1998). Factors that affect soil boron availability to plants include soil moisture, texture, temperature and organic matter content. Boron availability increases with increasing soil moisture, clay content, and organic matter content (Goldberg, 1997).

Soybean is one of the most B-demanding annual crops, especially at the beginning of the reproductive stage (Furlani et al., 2001; Carvalho; Nakagawa, 2012). The time of fertiliser application affects production of soybean beans and seeds because the nutrient demand by soybean plants is highest during stages R1 to R5 (Rosolem and Boaretto, 1989). Boron plays a role in plant fertilisation, and its demand is usually higher during seed and bean formation than vegetative growth (Faquin, 1994). The optimum boron dose recommended for soybean crops is $1.5 \mathrm{~kg} \mathrm{ha}^{-1} \mathrm{~B}$ according to Embrapa Soja (1999). Several studies have shown high variability of response to boron application (Ceretta et al., 2005).

Defining the ideal timing and dose of boron application to soybean is essential to increase soybean production. The aim of the present study was to determine the appropriate dose and phenological stage for boron application to two soybean cultivars, one transgenic and one conventional.

\section{Results and Discussion}

\section{Growth variables and yield}

The results of the combined ANOVA, for all parameters evaluated, are shown in Table 1. All parameters were significantly affected by one or more of the tested factors. A significant interaction between soybean variety, phenological stage and B dose (V x P x D) was observed for leaf boron concentration (Table 1). The relationship between leaf boron concentration and boron doses, for each phenological stage and soybean variety, best fit a simple linear regression model (Fig $1 \mathrm{~A}$ and $1 \mathrm{~B}$ ). B applications in stage V6, V9 and R1 resulted in average increases in leaf boron concentration of $89.47 \%, 68.83 \%$ and $59.97 \%$, respectively, for conventional soybean (Figure $1 \mathrm{~A}$ ) and $127.3 \%, 83.77 \%$ and $30 \%$, respectively, for transgenic soybean (Fig 1 B). No significant differences between the two soybean varieties were observed, except for a greater increase in leaf boron concentration for transgenic than for conventional soybean in plants receiving boron fertilisation at stage V6.

Leaf boron concentration increased linearly with increasing boron doses applied at different phenological stages. These results are in contrast with those of Rosolem et al. (2008), who observed a quadratic response of leaf B concentrations with increasing B fertilisation. The authors attributed this to B leaching, which increased with increasing doses of B fertilisation. However, Fageria (2000) evaluated soybean grown in Dark-Red Latosol in the Cerrado (Brazilian savanna) and observed toxicity with soil application of 5.2 $\mathrm{mg} \mathrm{kg}^{-1} \mathrm{~B}$.

A significant interaction between phenological stage and B dose $(\mathrm{P} \times \mathrm{D})$ and a significant effect of soybean variety were observed for chlorophyll concentration, indicating that boron fertilisation affected the SPAD chlorophyll concentration in the leaves of conventional and transgenic soybean cultivars, depending on the phenological stage and dose of boron fertilisation (Table 2). This may be due to the role of $\mathrm{B}$ on nitrogen metabolism and hormone activity (Dechen; Nachtigall, 2007), in addition to its essential role on sugar translocation and carbohydrate metabolism. Chlorophyll concentrations were higher for transgenic soybean (39.99 SPAD) than conventional soybean (36.98 SPAD) (Table 3). These data are in accordance with Hopkins (1999), who reported that chlorophyll is the main pigment responsible for the capture of light energy used in photosynthesis and one of the main determining factors of plant photosynthetic efficiency because it is directly related to crop growth, development and productivity (Engel and Poggiani, 1991). For chlorophyll concentration, the application of $3 \mathrm{~kg} \mathrm{~B} \mathrm{ha}^{-1}$ at stage $\mathrm{R} 1$ is the least recommended for conventional soybean because during stage R1, the plant is beginning to flower, and little of the B applied as fertiliser will be taken and used by the plant (Table 2). No other significant effects of $\mathrm{B}$ fertilisation were observed on chlorophyll concentrations for any of the phenological stages and doses of boron fertilisation or for conventional soybean or transgenic soybean. Chlorophyll concentrations presented a low coefficient of variation (6.43), indicating experimental precision (Carvalho et al., 2003).

Plant height was only significantly affected by soybean variety (Table 1). Plant height was $32.6 \%$ higher in conventional soybean $(85.34 \mathrm{~cm})$ than in transgenic soybean $(64.32 \mathrm{~cm})($ Table 3). This difference may be due to genetic differences between varieties. Kappes et al. (2008) observed a significant effect of B foliar fertilisation (290.5 $\mathrm{g} \mathrm{B} \mathrm{ha}^{-1}$ ) applied at vegetative stage V5 on soybean height, resulting in a maximum plant height of $72 \mathrm{~cm}$. In that same study, the highest plant height $(74 \mathrm{~cm})$ was observed with application of $293.5 \mathrm{~g} \mathrm{~B} \mathrm{ha}^{-1}$ at stage V9. However, no positive effects were observed for B application at stage R3. Nutrient utilisation for height growth is therefore lower during R3. Although dry matter accumulation begins in the vegetative parts of the plant, it is gradually translocated towards the formation of pods and beans between stages R3 and R5 (Potafos, 1997). Plant height is considered an important trait of soybean because it is directly related to production, weed control, plant lodging, and mechanical harvest efficiency. Height growth depends on stem elongation, which depends on the number and length of the internodes (Taiz and Zeiger, 2004). Stem diameter was only significantly affected by soybean variety $(\mathrm{V})$ (Table 1). Stem diameter was higher in transgenic soybean than in conventional soybeans (Table 3). This is in contrast with Raimundi et al. (2013), who reported that boron fertilisation affected plant physiological processes such as sugar transportation and cell wall structure and synthesis, resulting in significantly higher stem diameter, conferring greater plant rigidity and making plant lodging due to environmental or mechanical damage more difficult.

Height of first pod insertion was significantly affected by soybean variety (Table 1), and it was lower for transgenic soybean (average $9.11 \mathrm{~cm}$ ) than for conventional soybean $(12.75 \mathrm{~cm})$ (Table 3). This difference may be due to the different characteristics of the two varieties. Lower height may affect the harvest, resulting in bean contamination with soil or straw. Boron fertilisation did not result in higher height of first pod insertion. The height of first pod insertion is mostly related to cultivar genetics (Guimarães et al., 2008). However, plant height is lower in regions with shorter days, which results in a tendency of pod development close to the ground, which was not evaluated in the present study.

The number of pods was only significantly affected by soybean variety. The number of pods was higher for transgenic soybean (54.21) than for conventional soybean 


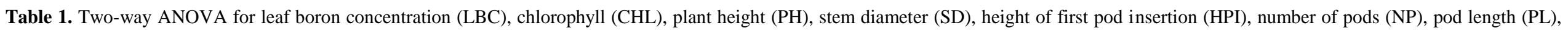

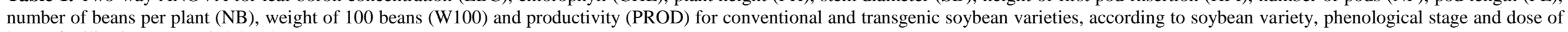
boron fertilisation. Ipameri-GO, 2015.

\begin{tabular}{|c|c|c|c|c|c|c|c|c|c|c|c|}
\hline \multirow{2}{*}{ Source of variation } & \multicolumn{3}{|c|}{ VALUE-P } & \multirow[b]{2}{*}{ PH } & \multirow[b]{2}{*}{ SD } & \multirow[b]{2}{*}{ HPI } & \multirow[b]{2}{*}{ NP } & \multirow[b]{2}{*}{ PL } & \multirow[b]{2}{*}{ NB } & \multirow[b]{2}{*}{ W100 } & \multirow[b]{2}{*}{ PROD } \\
\hline & GL & LBC & CHL & & & & & & & & \\
\hline Varieties (V) & 1 & $0.21^{\mathrm{ns}}$ & $<0.01 * *$ & $<0.01 * *$ & $<0.01 * *$ & $<0.01 * *$ & $0.01 * *$ & $0.02 *$ & $<0.01 * *$ & $<0.01 * *$ & $<0.01 * *$ \\
\hline Stage (S) & 2 & $<0.01 * *$ & $0.94^{\mathrm{ns}}$ & $0.18^{\mathrm{ns}}$ & $0.40^{\mathrm{ns}}$ & $0.10^{\mathrm{ns}}$ & $0.69^{\mathrm{ns}}$ & $0.90^{\mathrm{ns}}$ & $0.83^{\mathrm{ns}}$ & $0.67^{\mathrm{ns}}$ & $0.54^{\mathrm{ns}}$ \\
\hline Dose (D) & 4 & $<0.01 * *$ & $0.06^{\mathrm{ns}}$ & $0.06^{\mathrm{ns}}$ & $0.39^{\mathrm{ns}}$ & $0.40^{\mathrm{ns}}$ & $0.38^{\mathrm{ns}}$ & $0.92^{\text {ns }}$ & $0.36^{\mathrm{ns}}$ & $0.05 *$ & $0.05 *$ \\
\hline Block/ Varieties & 6 & $0.02 *$ & $0.021^{\mathrm{ns}}$ & $0.05 * *$ & $0.80^{\mathrm{ns}}$ & $<0.01 * *$ & $0.06^{\mathrm{ns}}$ & $0.03 *$ & $0.18^{\mathrm{ns}}$ & $<0.01 * *$ & $0.99^{\mathrm{ns}}$ \\
\hline $\mathrm{S} \times \mathrm{D}$ & 8 & $<0.01 * *$ & $0.003 * *$ & $0.91^{\mathrm{ns}}$ & $0.51^{\mathrm{ns}}$ & $0.09^{\mathrm{ns}}$ & $0.32^{\mathrm{ns}}$ & $0.36^{\mathrm{ns}}$ & $0.14^{\mathrm{ns}}$ & $0.92^{\mathrm{ns}}$ & $0.39^{\mathrm{ns}}$ \\
\hline $\mathrm{V} \times \mathrm{S}$ & 2 & $<0.01 * *$ & $0.66^{\mathrm{ns}}$ & $0.45^{\mathrm{ns}}$ & $0.43^{\mathrm{ns}}$ & $0.66^{\mathrm{ns}}$ & $0.91^{\mathrm{ns}}$ & $0.93^{\mathrm{ns}}$ & $0.32^{\mathrm{ns}}$ & $0.65^{\mathrm{ns}}$ & $0.66^{\mathrm{ns}}$ \\
\hline$V \times D$ & 4 & $0.29^{\mathrm{ns}}$ & $0.09^{\mathrm{ns}}$ & $0.10^{\mathrm{ns}}$ & $0.82^{\text {ns }}$ & $0.98^{\mathrm{ns}}$ & $0.99^{\mathrm{ns}}$ & $0.60^{\mathrm{ns}}$ & $0.90^{\mathrm{ns}}$ & $0.02 * *$ & $0.09^{\mathrm{ns}}$ \\
\hline \multirow[t]{2}{*}{$\mathrm{V} \times \mathrm{D} \times \mathrm{S}$} & 8 & $<0.01 * *$ & $0.12^{\mathrm{ns}}$ & $0.81^{\mathrm{ns}}$ & $0.10^{\mathrm{ns}}$ & $0.71^{\mathrm{ns}}$ & $0.81^{\mathrm{ns}}$ & $0.32^{\text {ns }}$ & $0.06^{\mathrm{ns}}$ & $0.76^{\mathrm{ns}}$ & $0.27^{\mathrm{ns}}$ \\
\hline & & SQUARI & $\overline{\mathrm{AN}}$ & & & & & & & & \\
\hline Residue & 84 & 9.77 & 5.65 & 40.8 & 1.62 & 6.67 & 114.5 & 0.75 & 350.8 & 1.84 & 1247.11 \\
\hline Averages & --- & 47.23 & 58.48 & 107.00 & 10.08 & 15.48 & 78.83 & 5.60 & 165.19 & 23.53 & 2531.79 \\
\hline CV $(\%)$ & --- & 6.61 & 4.06 & 5.96 & 7.99 & 16.80 & 13.57 & 15.46 & 11.33 & 8.94 & 13.94 \\
\hline
\end{tabular}

${ }^{*}$ Significant according to the $\mathrm{F}$ test at $p<0.05$; ${ }^{* *}$ Significant according to the $\mathrm{F}$ test at $p<0.01$; ${ }^{\text {ns }}$ not significant.
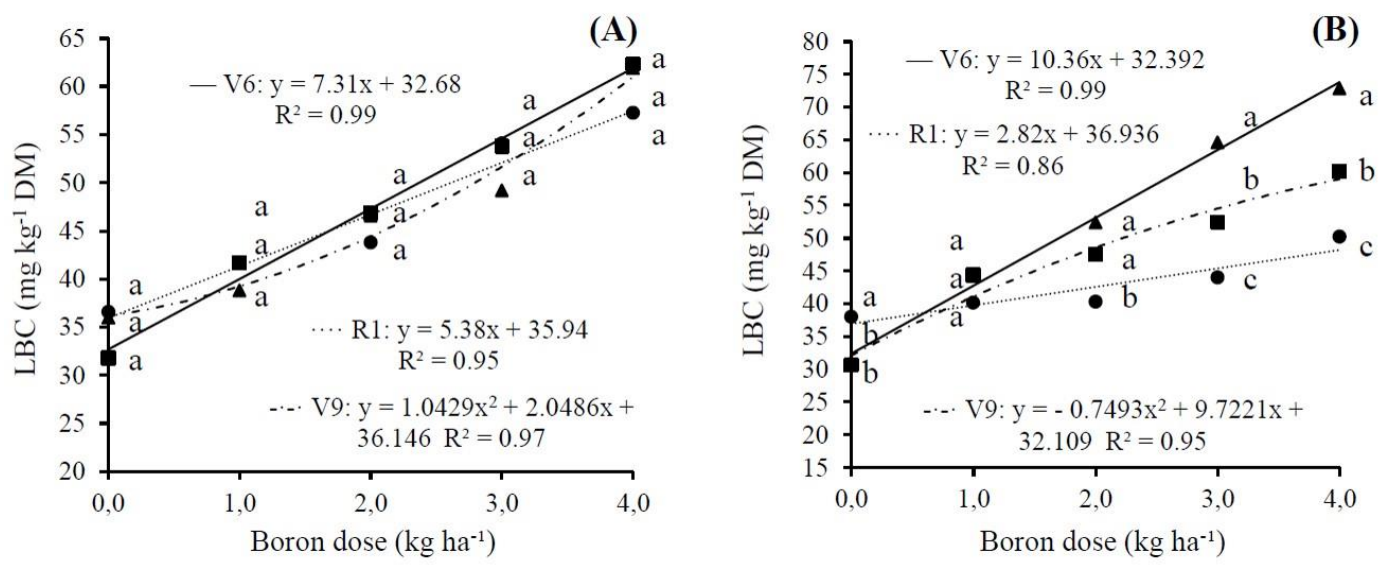

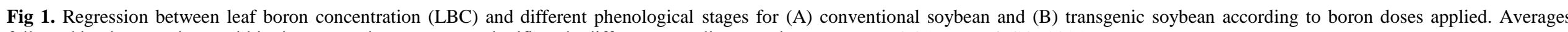
followed by the same letter within the same column were not significantly different according to Tukey's test at $p<0.05$. Ipameri-GO, 2015 . 
Table 2. Average chlorophyll concentration (SPAD) according to the dose and phenological stage of boron fertilisation and soybean variety. Ipameri-GO, 2015.

\begin{tabular}{|c|c|c|c|}
\hline \multirow{2}{*}{ Dose/Stage } & \multicolumn{3}{|c|}{ Conventional soybean } \\
\hline & V6 & V9 & R1 \\
\hline 0 & $36.35 \mathrm{a}$ & $36.78 \mathrm{a}$ & $37.66 \mathrm{a}$ \\
\hline 1 & $35.87 \mathrm{a}$ & $38.75 \mathrm{a}$ & $38.26 \mathrm{a}$ \\
\hline 2 & $36.72 \mathrm{a}$ & $39.42 \mathrm{a}$ & $38.21 \mathrm{a}$ \\
\hline 3 & $37.56 \mathrm{a}$ & $36.70 \mathrm{a}$ & $31.58 \mathrm{~b}$ \\
\hline \multirow[t]{2}{*}{4} & $37.45 \mathrm{a}$ & $34.56 \mathrm{a}$ & $38.86 \mathrm{a}$ \\
\hline & Transgenic & & \\
\hline 0 & $38.94 \mathrm{a}$ & $38.48 \mathrm{a}$ & $39.72 \mathrm{a}$ \\
\hline 1 & $40.63 \mathrm{a}$ & $38.93 \mathrm{a}$ & $40.44 \mathrm{a}$ \\
\hline 2 & $39.33 \mathrm{a}$ & $38.68 \mathrm{a}$ & $41.18 \mathrm{a}$ \\
\hline 3 & $40.53 \mathrm{a}$ & $41.10 \mathrm{a}$ & $37.40 \mathrm{a}$ \\
\hline 4 & $42.24 \mathrm{a}$ & $41.99 \mathrm{a}$ & $40.59 \mathrm{a}$ \\
\hline
\end{tabular}
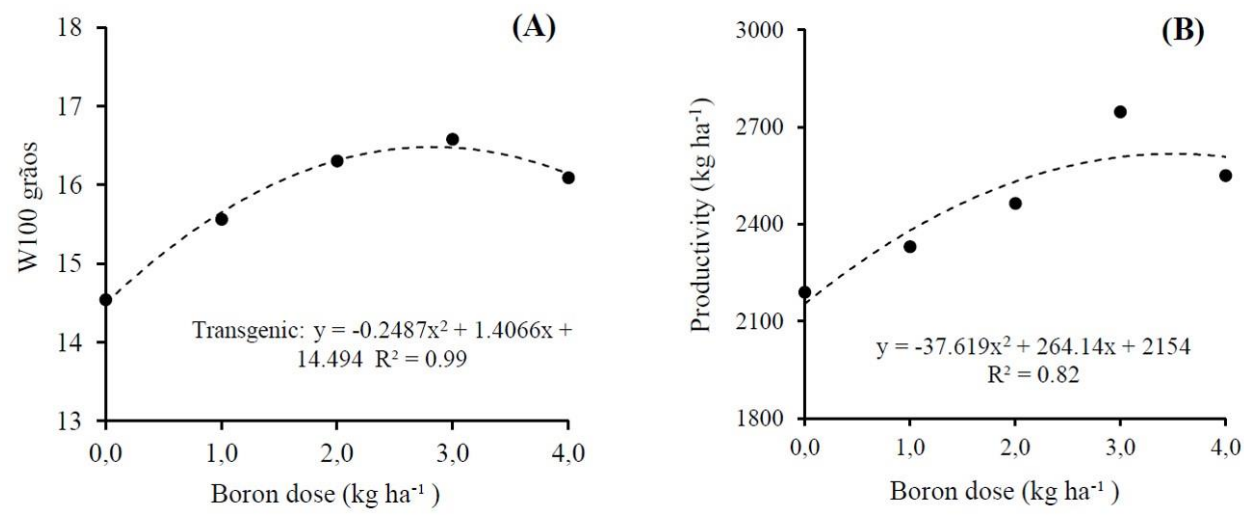

Fig 2. (A) Weight of 100 beans (W100 beans) according to B dose and soybean variety, and (B) soybean productivity according to B dose. Ipameri-GO, 2015.

Table 3. Overall average of leaf boron concentration (LBC), chlorophyll concentration (CHL), plant height (PH), stem diameter (SD), height of first pod insertion (HPI), number of pods (NP), pod length (PL), number of beans per plant (NB), weight of 100 beans (W100) and productivity (PROD) for conventional and transgenic soybean varieties. Ipameri-GO, 2015.

Averages followed by the same letter within the same column were not significantly different according to Tukey's test, at $p<0.05$.

\begin{tabular}{lllllllllll}
\hline \multirow{2}{*}{ Variedades } & LBC & CHL & PH & SD & HPI & NP & PL & NB & W100 & PROD \\
\cline { 2 - 10 } & $\mathrm{mg} \mathrm{kg}^{-1}$ & $(\mathrm{Spad})$ & $(\mathrm{cm})$ & $(\mathrm{mm})$ & $(\mathrm{cm})$ & ---- & $(\mathrm{cm})$ & --- & $(\mathrm{g})$ & $(\mathrm{kg} \mathrm{ha})$ \\
\hline Conventional & $46.8 \mathrm{a}$ & $39.9 \mathrm{a}$ & $85.3 \mathrm{a}$ & $6.2 \mathrm{~b}$ & $12.7 \mathrm{a}$ & $49.2 \mathrm{~b}$ & $4.0 \mathrm{a}$ & $87.4 \mathrm{~b}$ & $14.5 \mathrm{~b}$ & $1.294 \mathrm{~b}$ \\
Transgenic & $47.5 \mathrm{a}$ & $36.9 \mathrm{a}$ & $64.3 \mathrm{~b}$ & $6.9 \mathrm{a}$ & $9.1 \mathrm{~b}$ & $54.2 \mathrm{a}$ & $3.6 \mathrm{~b}$ & $121.4 \mathrm{a}$ & $16.2 \mathrm{a}$ & $1.884 \mathrm{a}$ \\
\hline CV\% & 6.6 & 4.0 & 5.9 & 7.9 & 16.8 & 13.5 & 15.4 & 11.3 & 8.9 & 13.9 \\
\hline
\end{tabular}

(49.23) (Table 3). Pod length and number of beans per plant were also significantly affected by soybean variety (Table 1 ). Pod length was $4 \mathrm{~cm}$ for conventional soybean, and $3.6 \mathrm{~cm}$ for transgenic soybean (Table 3). The number of beans per plant was $38.9 \%$ higher for transgenic soybean than for conventional soybean (Table 3). Silva et al. (2006) found no significant differences in these parameters in bean crops. The number of beans per plant is related to the plant variety and is minimally affected by environmental factors (Andrade et al., 1998). Marschner (1995) reported that the absence of calcium and boron may affect pollen germination and pollen tube growth, resulting in lower number of seeds per pod. Silva et al. (2006) studied calcium and boron foliar fertilisation in bean and also did not observe significant differences in the number of pods per plant.

A significant interaction between soybean variety and B dose $(\mathrm{V} \times \mathrm{D})$ was observed for the weight of 100 beans (Table 1). Variations in the weight of 100 beans best fit a quadratic regression for transgenic soybean, with maximum value at $2.8 \mathrm{~kg} \mathrm{ha}^{-1} \mathrm{~B}$ (Fig 2A), whereas it decreased with increasing B doses for conventional soybean (Fig 2A). These data confirm the effect of boron fertilisation on sugar translocation to plant reproductive organs (Malavolta et al., 2002). However, the weight of 100 beans is most often related to the genetic variability of each cultivar. Similar results were reported by Bevilaqua et al. (2002), who studied soybean cultivar BR 16 and observed that $\mathrm{Ca}$ and $\mathrm{B}$ foliar fertilisation increased the weight of 100 beans when applied during the flowering stage. In contrast with the present study, several authors did not observe significant effects of soybean boron fertilisation applied at different phenological stages on the weight of 100 beans. Kappes et al. (2008) studied B foliar fertilisation at different doses $(0,100,200,300$ or $400 \mathrm{~g} \mathrm{~B}$ ha $\left.{ }^{1}\right)$ applied in different times and observed no positive effect on the weight of 100 beans. Calonego et al. (2010) studied soybean B foliar fertilisation at different doses and applied at different phenological stages and did not observe a significant differences in the weight of 100 beans. These authors reported an average weight of 100 beans of $12.8 \mathrm{~g}$, 
lower than the $16.26 \mathrm{~g}$ observed in the present study for transgenic soybeans (Table 3 ).

In contrast, Souza et al. (2008) observed that B fertilisation resulted in significantly higher weight of 100 beans, indicating higher dry matter accumulation, when applied at stage R3 (11.9 g) than when applied at stage R1 (11.4 g).

The combined ANOVA showed a significant effect of soybean variety (V) and B dose (D) on plant productivity (Table 1). Productivity was on average $45.5 \%$ higher for transgenic soybean (1884 $\left.\mathrm{kg} \mathrm{ha}^{-1}\right)$ than for conventional soybean (1294 kg ha-1) (Table 3). This result was expected because the transgenic variety has higher production than the conventional variety due to its genetic improvement

Productivity variations depending on boron doses best fit quadratic models (Fig 2B) and was highest (2617 kg ha $\left.{ }^{-1}\right)$ at $3.51 \mathrm{~kg} \mathrm{~B} \mathrm{ha}{ }^{-1}$. Productivity decreased with higher B doses, indicating a toxic effect as observed in the present study for the highest $\mathrm{B}$ dose tested $\left(4 \mathrm{~kg} \mathrm{~B} \mathrm{ha}^{-1}\right)$. Fageria (2000) performed a greenhouse experiment for the determination of optimal and toxic boron doses for soybean dry matter production and observed toxicity symptoms with the soil application of $6.8 \mathrm{mg} \mathrm{B} \mathrm{kg}^{-1}$. Castagnel and Silva (2009) observed that boron fertilisation significantly improved the reproductive development of bean plants and, therefore, bean productivity, independent of the time of fertilisation. Rezende et al. (2005) observed higher bean production in soybeans and concluded that this higher productivity was related to leaf nutrient replenishment through boron fertilisation, resulting in sustained maintenance of the photosynthetic rate.

In contrast, Calonego et al. (2010) observed that boron foliar fertilisation did not affect bean productivity in soybean. Macedo et al. (2002) and Kappes (2008) did not observe significant effects of calcium and boron fertilisation, applied in different phenological stages and doses, on soybean productivity. Lima et al. (1999) evaluated the effect of boron foliar fertilisation at different doses $\left(0,20\right.$ and $\left.40 \mathrm{~g} \mathrm{ha}^{-1}\right) 30$ days following seedling emergence of bean cultivar Carioca, in winter or the rainy season, and did not observe any significant effects on productivity, nor did Silva et al. (2006) observe significant effects of boron on productivity of bean plants.

Further studies of boron fertilisation in soybean are needed because different responses to boron doses, phenological stages of B application, type of soil and altitude have been observed.

\section{Materials and Methods}

\section{Location and installation of the experiments}

Two different soybean varieties were tested in two field experiments performed in parallel during the 2014/2015 season. The two experiments were located based on agricultural zoning, in the experimental area of the State University of Goiás, Ipameri Campus, located in Ipameri, Goiás state (GO), Brazil, at $17^{\circ} 43^{\prime} 04$ ' $\mathrm{S}, 48^{\circ} 08^{\prime} 43^{\prime}$ ' W and an altitude of $794 \mathrm{~m}$.

The region has a Tropical Savanna climate (AW) according to the Köppen climate classification, with hot and rainy summers and dry winters. The soil at the experimental area is classified as Yellow-Red Dystrophic Latosol according to Santos et al. (2013).

Soil chemical characteristics and particle size were analysed before starting the experiment using the process described by Ribeiro et al. (1999). Soil from layer 0.0-0.20 m exhibited the following characteristics: $6.4 \mathrm{mg} \mathrm{dm}^{-3} \mathrm{P}$ (Mehlich-1); $20 \mathrm{~g} \mathrm{dm}^{-3}$ organic matter (OM); $\mathrm{pH} 4.7\left(\mathrm{CaCl}_{2}\right)$;
$2.5 \mathrm{mmol}_{\mathrm{c}} \mathrm{dm}^{-3} \mathrm{~K} ; 10.0 \mathrm{mmol}_{\mathrm{c}} \mathrm{dm}^{-3} \mathrm{Ca} ; 4 \mathrm{mmol}_{\mathrm{c}} \mathrm{dm}^{-3} \mathrm{Mg} ; 35$ $\mathrm{mmol}_{\mathrm{c}} \mathrm{dm}^{-3} \mathrm{H}+\mathrm{Al} ; 32 \%$ base saturation; and $0.4 \mathrm{mg} \mathrm{dm}^{-3} \mathrm{~B}$. The soil B level observed is considered medium. The soil particle size composition was $475 \mathrm{~g}$ clay, $75 \mathrm{~g}$ silt, and $450 \mathrm{~g}$ sand.

\section{Statistical design and Plant materials}

A randomised block experimental design was used for both experiments, with a $3 \times 5$ factorial scheme and four replicates per treatment. The first factor was the phenological stage of boron application and had three levels: V6 (seven fully expanded trifoliate leaves), V9 (ten fully expanded trifoliate leaves), and R1 (beginning of flowering). The second factor was the boron dose and had five levels: $0,1,2,3$ and $4 \mathrm{~kg}$ ha 1 . Boron was applied to the soil as boric acid (17\%). Two experiments were performed, one with the conventional soybean variety BRS 7980 and one with the intact transgenic variety M 7739 IPRO, both with medium cycles. Each plot consisted of six rows, $5 \mathrm{~m}$ long, spaced $0.45 \mathrm{~m}$ apart, with a total area of $13.5 \mathrm{~m}^{2}$. Fifteen plants were planted per linear metre. The useful area consisted of the three central rows, excluding $1 \mathrm{~m}$ from the row extremities.

A no-tillage planting system was used on Brachiaria decumbens straw. Plants were sown on 19 November 2014. Fertilisation at planting was performed based on the soil analysis, following Ribeiro et al. (1999), with application of $450 \mathrm{~kg}$ of a $2: 20: 18$ formulation of $\mathrm{N}: \mathrm{P}_{2} \mathrm{O}_{5}: \mathrm{K}_{2} \mathrm{O}$.

Sowing was performed using tractor-mounted seederfertiliser spreaders with eight lines, equipped with horizontal perforated disks for seed distribution, and a furrower for fertiliser deposition.

Boron was applied manually at different soybean phenological stages according to the staging system for soybean cultivars described by Ritchie et al. (1994). All remaining crop treatments during the experiments were performed mechanically, using tractor-mounted sprayers.

\section{Evaluated characteristics}

The following parameters were determined: leaf boron concentration, chlorophyll concentration, yield components, productivity and seed physiological quality. For leaf boron concentration, the third leaf (counting from the apex of the main stem) and its petiole were collected from 10 plants from each plot at the flowering stage (R3) (Martinez et al., 1999). The leaves were dried in a forced air oven at $65^{\circ} \mathrm{C}$ for approximately 48 hours, ground using a Wiley mill with a 1 $\mathrm{mm}$ sieve, and placed in paper bags until analysis. Samples were prepared according to Wikner (1986) and Bataglia (1991), and leaf boron concentrations were determined according to Malavolta et al. (1997). For chlorophyll concentration, the leaf chlorophyll concentrations were measured indirectly by determining the SPAD index using a clorofiLOG CFL1030 portable chlorophyll metre. Measurements were performed in six leaves located in the middle third of six plants sampled randomly from each plot, and the average for each plot was calculated.

Six plants were collected from the useful area of each plot at harvest and taken to the laboratory for determination of the yield components. Plant height was measured from the ground to the plant apex, in centimetres, in plants chosen randomly at each plot, and the average was calculated. Stem diameter was measured at the stem base using a digital pachymeter with a precision of two decimal places. Height of first pod insertion was measured as the height from the ground to the first pod. Number of pods per plant was 
determined by collecting and counting all pods in each plant from each plot. Pod length was measured, using a graduated ruler, as the length between the two pod extremities. Number of beans per plant was measured by counting the number of beans present in all pods of plant. Weight of 100 beans was determined by collecting and weighing 100 beans from each plot using a precision scale. Bean productivity $\left(\mathrm{kg} \mathrm{ha}^{-1}\right)$ was determined by harvesting and threshing all plants from the three central rows from each plot (useful plot area). To calculate post-threshing productivity, the bean water content was adjusted to $13 \%$, impurities were deducted, and bean productivity was expressed in $\mathrm{kg} \mathrm{ha}^{-1}$.

\section{Statistical analysis}

A combined ANOVA, followed by Tukey's test, was used to test for the effects of soybean variety and phenological stages, at $\mathrm{p}<0.05$. Regression analyses were used to test for the effect of different B doses. All statistical analyses were performed using R 3.1.2 software (R Core Team, 2015).

\section{Conclusion}

Boron fertilisation at different phenological stages did not affect most agronomic traits evaluated either in conventional soybean or transgenic soybean. However, it increased productivity in both varieties, independent of the phenological stage of $\mathrm{B}$ fertilisation.

The $\mathrm{B}$ dose indicated for maximum soybean production, for both varieties tested, was $3.51 \mathrm{~kg} \mathrm{~B} \mathrm{ha}^{-1}$.

\section{Conflict of interests}

The authors have not declared any conflict of interests.

\section{Acknowledgments}

The authors wish to thank the State University of Goiás (Universidade Estadual de Goiás), Ipameri Campus for support in setting up and conducting the present project and the Federal Institute of Goiás (Instituto Federal Goiano), Urutaí Campus for financial support.

The Federal Institute Goiano (Instituto Federal Goiano) the productivity scholarship PAPPE to the second author, e the Goiás State University (Universidade Estadual de Goiás) the productivity scholarship PROBIP to the fifth author.

\section{References}

Andrade MJB, Diniz AR, Carvalho JG, Lima SF (1998) Resposta da cultura do feijoeiro à aplicação foliar de molibdênio e às adubações nitrogenadas de plantio e cobertura. Ciênc Agrotec. 22:499-508.

Bataglia OC. Análise química de plantas. In: Ferreira ME, Cruz MCP (Org.) (1991) Micronutrientes na agricultura. Piracicaba: POTAFOS/CNPQ, p. 298-308.

Bevilaqua GAP, Silva Filho PM, Possenti JC (2002) Aplicação foliar de cálcio e boro e componentes de rendimento e qualidade de sementes de soja. Ciênc Rural. 32:31-34.

Blevins DG, Lukaszewski KM (1998) Boron in plant structure and function. Annu Rev Plant Biol. 49:481-500.

Brown PH, Hu H (1994) Boron uptake by sunflower, squash, and cultured tobacco cells. Physiol Plantarum. 91:435-441.

Calonego JC, Ocani K, Ocani M, Santos CH (2010) Adubação boratada foliar na cultura da soja. Colloq Agrar. 6:20-26.
Carvalho CGP, Arias CAA, Toledo JFF, Almeida LA, Kiihl RAS, Oliveira MF, Hiromoto DM, Takeda C (2003) Proposta de classificação dos coeficientes de variação em relação à produtividade e altura de planta de soja. Pesq Agrop Bras. 38:187-193.

Carvalho NM, Nakagawa J (2012) Sementes: ciência, tecnologia e produção. 5.ed. Jaboticabal: FUNEP. 590p.

Castagnel J, Silva TRB (2009) Adubação foliar de boro na cultura do feijão. Cult saber. 2:7-16.

Ceretta CA, Pavinato A, Pavinato PS, Moreira ICL, Girotto E, Trentin EE (2005) Micronutrientes na soja: produtividade e análise econômica. Ciênc Rural. 35:576581.

Conab (Companhia Nacional de Abastecimento. Acompanhamento de Safra Brasileira) (2016) Grãos, Quinto Levantamento. Fevereiro/2016. Disponível em:<www.conab.gov.br/OlalaCMS/uploads/arquivos/16_0 2_04_11_21_34_boletim_graos_fevereiro_2016_ok.pdf $>$. Acesso em: 10 fev. 2016.

Cunha RC, Espíndola CJA (2015) A dinâmica geoeconômica recente da cadeia produtiva da soja no Brasil e no mundo. GeoTextos. 11:217-238.

Dechen AR, Nachtigall GR (2007) Elementos requeridos à nutrição de plantas. In: Novais RF, Alvarez VVH, Barros NF, Fontes RLF, Cantarutti RB, Neves JCL. (Eds). Fertilidade do Solo. Viçosa-MG: SBCS/UFV, p. 92-132.

Embrapa Soja (1999) Recomendações técnicas para a cultura da soja no Paraná 1999/2000. Londrina, 236p. (Embrapa Soja. Documentos, 131).

Engel VL, Poggiani F (1991) Estudo da concentração de clorofila nas folhas e seu espectro de absorção de luz em função do sombreamento em mudas de quatro espécies florestais nativas. Rev Bras Fisiol Veg. 3:39-45.

Fageria NK (2000) Níveis tóxicos de boro na produção de arroz, feijão, milho, soja e trigo em solo de cerrado. Rev Bras Eng Agríc Ambient. 4:57-62.

Faquin V (1994) Nutrição mineral de plantas. Lavras: ESAL/FAEPE, p.227.

Ferreira Junior JA, Espindola SMCG, Gonçalves DAR, Lopes EW (2010) Avaliação de genótipos de soja em diferentes épocas de plantio e densidade de semeadura no município de Uberaba - MG. Fazu em revista. Agronomia 7:13-21.

Furlani AMC, Tanaka RT, Tarallo M, Verdial MF, Mascarenhas HAA (2001) Exigência a boro em cultivares de soja. Rev Bras Ciênc Solo. 25:929-937.

Goldberg S (1997) Reactions of boron with soils. In: Dell B, Brown PH, Bell RW. Boron in soils and plants: Reviews. Dordrechet: Kluwer Academic. 35-48.

Guimarães FS, Rezende PM, Castro EM, Carvalho EA, Andrade MJB, Carvalho ER (2008) Cultivares de soja [Glycine max (L.) Merrill] para cultivo de verão na região de Lavras-MG. Ciênc Agrotec. 32:1099-1106.

Hopkins WG (1999) Introduction to Plant Physiology. New York: John Wiley e Sons, 512p.

Kappes C, Golo AL, Carvalho MAC (2008) Doses e épocas de aplicação foliar de boro nas características agronômicas e na qualidade de sementes de soja. Sc Agrar. 9:291-297.

Lima SF, Andrade MJB, Carvalho JG (1999). Resposta do feijoeiro à adubação foliar de boro, molibdênio e zinco. Ciênc Agrotec. 23:462-467.

Macedo FB, Teixeira NT, Lima AM, Bernardes CR, Freitas DJB, Oliveira RF (2002) Boro no Plantio e Cálcio e Boro em Adubação Foliar na Produção da Soja. Rev Ecossistema. 27:87-89.

Malavolta E, Pimentel Gomes F, Alcarde JC (2002) Adubos e adubações. São Paulo: Nobel, 199 p. 
Malavolta E, Vitti GC, Oliveira AS (1997) Avaliação do estado nutricional das plantas - princípios e aplicações. Piracicaba, POTAFOS, 319p.

Malavolta E, Vitti GC, Oliveira AS (1989) Avaliação do estado nutricional de plantas. Piracicaba, POTAFOS, p. 201.

Marschner H (1995) Mineral nutrition of higher plants. 2nd ed. San Diego, Academic Press. 889p.

Martinez HEP, Carvalho JG, Souza RB (1999) Diagnose foliar. In: Ribeiro AC, Guimarães PTG, Alvarez VH. Recomendações para o uso de corretivos e fertilizantes em Minas Gerais $-5^{\mathrm{a}}$ aproximação. Viçosa: UFV, 359p.

Pelaez V, Albergoni L, Guerra MP (2004) Soja transgênica versus soja convencional: uma análise comparativa de custos e benefícios. Cad Ciênc Tecnologia. 21:279-309.

Peske ST, Barros ACSA, Schuch LOB (2012) Produção de sementes. In: Peske ST, Villela FA, Meneghello GE. Sementes: Fundamentos Científicos e tecnológicos. 3.ed. Pelotas: Editora Universitária, UFPel, p.13-104.

Pires CV, Oliveira MGA, Rosa JC, Costa NMB (2006) Qualidade nutricional e escore químico de aminoácidos de diferentes fontes protéicas. Ciênc Tecnol Aliment. 26:179187.

Potafos (Associação Brasileira para a Pesquisa da Potassa e do Fosfato) (1997). Como a planta de soja se desenvolve. Piracicaba: Potafos, p. 20.

R Core Team. (2015) R: A language and environment for statistical computing [Programa informático]. Vienna: R Foundation for Statistical Computing.

Raimundi DL, Moreira GC, Turri LT (2013) Modos de aplicação de boro na cultura da soja. Cult Saber. 6:112-121.

Reis CJ, Soratto RP, Biscaro GA, Kulczynski SM, Fernandes DS (2008) Doses e modos de aplicação de boro na produção e qualidade fisiológica de sementes de feijão em solo de cerrado. Rev Ceres. 55:258-264.

Rezende PM, Gris CF, Carvalho JG, Gomes LL, Bottino L (2005) Adubação foliar. I. Épocas de aplicação de Fósforo na cultura da soja. Ciênc Agrotec. 29:1105-1111.

Ribeiro AC, Guimarães PTG, ALVAREZ VH. (1999) Recomendações para o uso de corretivos e fertilizantes em Minas Gerais - 5a. Aproximação. Viçosa: UFV, 359p.

Ritchie SW, Hanway JJ, Thompson HE (1994) How a Soybean Plant Develops. Ames: Iowa State University of Science and Technology Cooperative Extension Service, 1994. Adaptado por J.T. Yorinori, 1996.

Rosolem CA, Boaretto AE (1989) A adubação foliar em soja. In: Boaretto AE, Rosolem CA. Adubação foliar. Campinas, SP: Fundação Cargill, 500p.

Rosolem CA, Zancanaro L, Biscaro T (2008) Boro disponível e resposta da soja em latossolo vermelho-amarelo do Mato Grosso. Rev Bras Ciênc Solo. 32:2375-2383
Santos HG, Jacomine PKT, Anjos LHC, Oliveira VA, Lumbreras JF, Coelho MR, Almeida JA, Cunha TJF, Oliveira JB (2013) Sistema brasileiro de classificação de solos. 3.ed. rev. e ampl. Brasília: Embrapa, 353p.

Silva TRB, Soratto RP, Bíscaro T, Lemos LB (2006) Aplicação foliar de boro e cálcio no feijoeiro. Rev Científica. 34:46-52.

Souza LCD, Sá ME, Carvalho MAC, Simidu HM (2008) Produtividade de quatro cultivares de soja em função da aplicação de fertilizante mineral foliar a base de cálcio e boro. Rev Biol Ciênc Terra. 8:37-44.

Suzana CS, Brunetto A, Marangon D, Tonello A, Kulczynski SM (2012) Influência da Adubação foliar sobre a qualidade fisiológica das sementes de soja armazenadas. Enciclop Biosfera. 8:2385-2392.

Taiz L, Zeiger E, Santarém ER (2004) Fisiologia vegetal. 3.ed. Porto Alegre: Artmed, p. 613.

Trautmann RR, Lana MC, Guimarães VF, Gonçalves Junior AC, Steiner F (2014) Potencial de água do solo é adubação com boro no crescimento e absorção do nutriente pela cultura da soja. Rev Bras Ciênc Solo. 38: 240-251.

Wikner B (1986) Pretreatment of plant and soil samples. A problem in boron analysis: Part I. Plants. Commun Soil Sci Plant Anal. p.1-25. 